\title{
S $\mathbf{U}^{-} \mathbf{A}=2$ JAN ARMOURED CAR PRODUCTION IN WORID WA 2 II
}

RICHARD CORNWELL

In the years immediately preceding the outbreak of World War II, the government of the Union of South Africa was already beginning to consider the mechanisation of its small field army. Early in 1937 the Ford Motor Company's factory at Port Elizabeth, South Africa, obtained drawings from their Cahadian offices, showing details of an experimental armoured car built for the Department of Defence in Ottawa, and based on the adaptation of a Crossley armoured car to a Ford chassis. The South African War Supplies Board was very interested in this project and approached the Ford Company at Port Elizabeth which had indicated that it would consider undertaking manufacture of a similar vehicle.

Later in 1937 the War Supplies Board began discussions with local firms in South Africa, and discovered that there were apparently no real problems involved in the manufacture of the armoured body or gun mountings for the cars. Meanwhile further information from the British War Office indicated the possibility of designing an armoured reconnaissance vehicle suitable for a Ford V8 6 wheeled chassis.
Early in 1938 local manufacturers were shown preliminary designs, but detailed development was held up by lack of trained technical staff in the South African Defence Department. Finally, towards the end of the year, the designs were reviewed again and a survey was made to find suitable works where construction could begin.

As yet, no decision had been taken on the final design, and in any case difficulties were being encountered in developing the requisite steels for armour at the South African Iron and Steel Corporation (Iscor). In April 1939 these problems seemed likely to impose serious delays on the project and an order was placed in the United States for 22 US Army pattern armoured cars of M1 type mounted on a Ford 6-wheeled chassis. Once this order had been placed the development of locally manufactured vehicles became less urgent, but by June it had been discovered that there were certain problems in adapting the American M1 design to the Ford chassis. In August the order for the 22 American cars was cancelled and in South Africa two mock-ups in soft steel of domestic design were ordered, one based on an ordinary

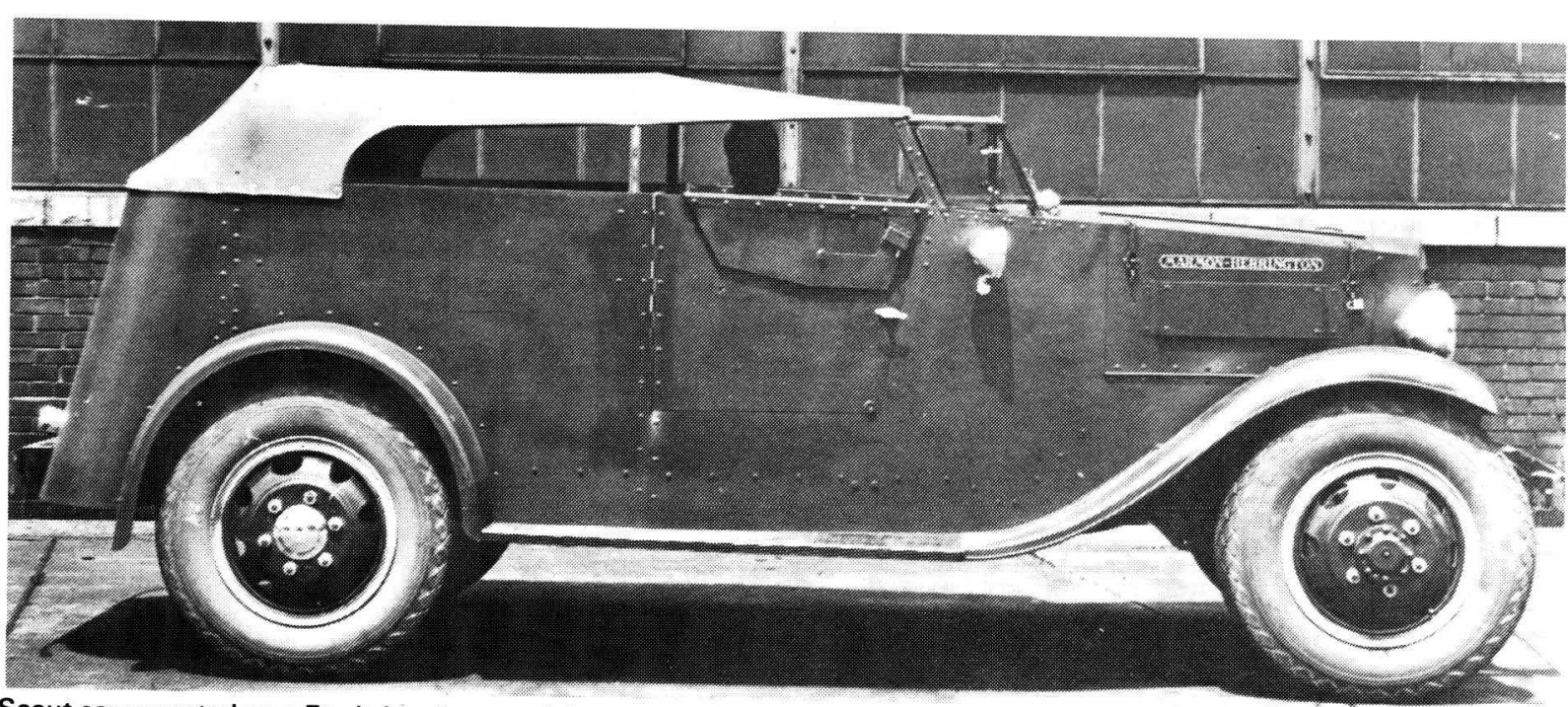

Scout car mounted on a Ford chassis: one of three types of armoured fighting vehicle inspected by the South African mission to the United States at the Marmon-Herrington factory in Indianapolis, June 1939. 


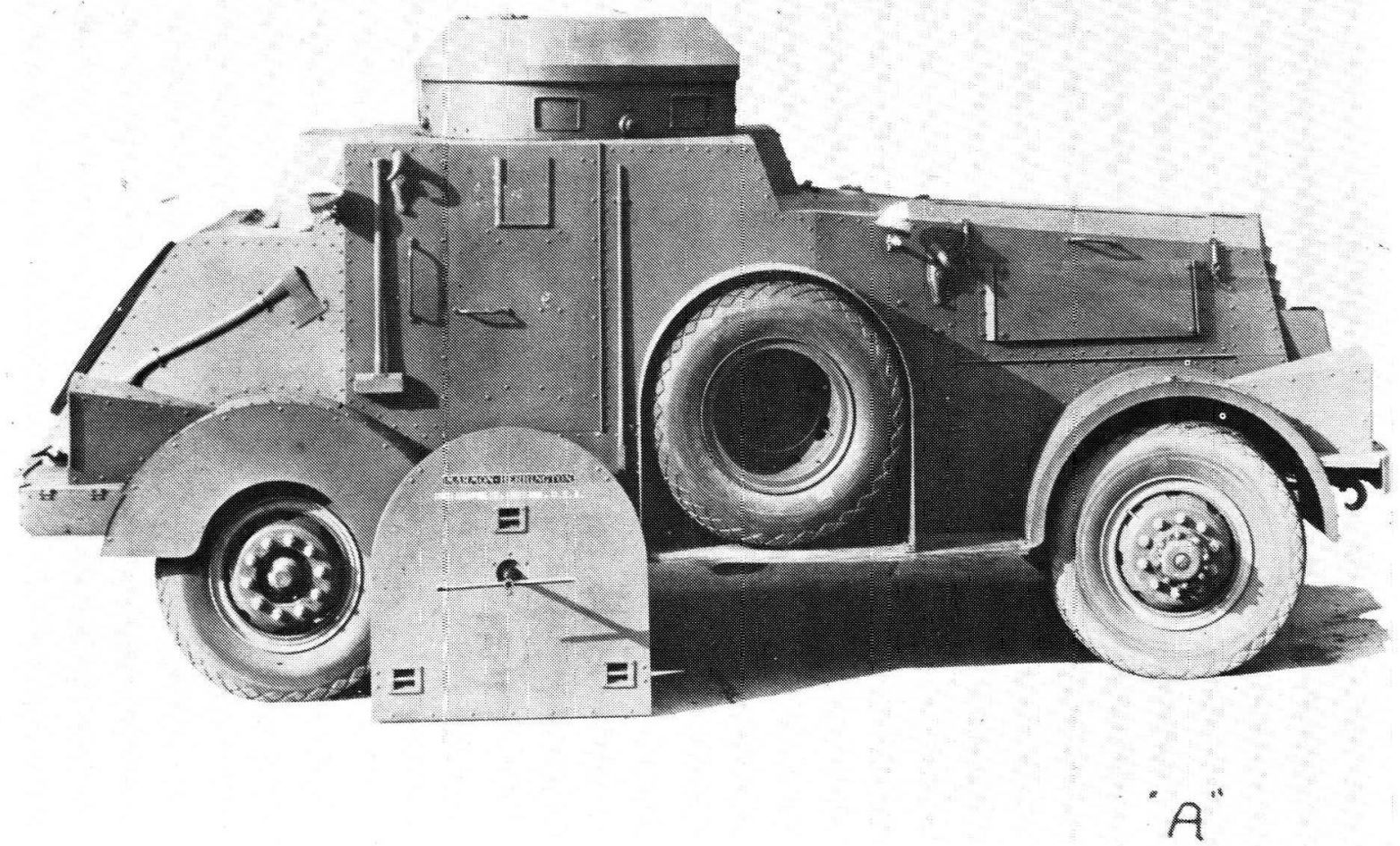

Marmon-Herrington armoured car supplied in large numbers to the Iranian Army by the United States, 1939.

Ford chassis and the other on a Ford with a fourwheel drive conversion provided by the MarmonHerrington Company of Indiana.

With the entry of South Africa into the war in September 1939 the armaments programme assumed a new urgency, and that December the design of the first model of what became known as the South African Reconnaissance Car Mark I was approved and arrangements were made to begin production.

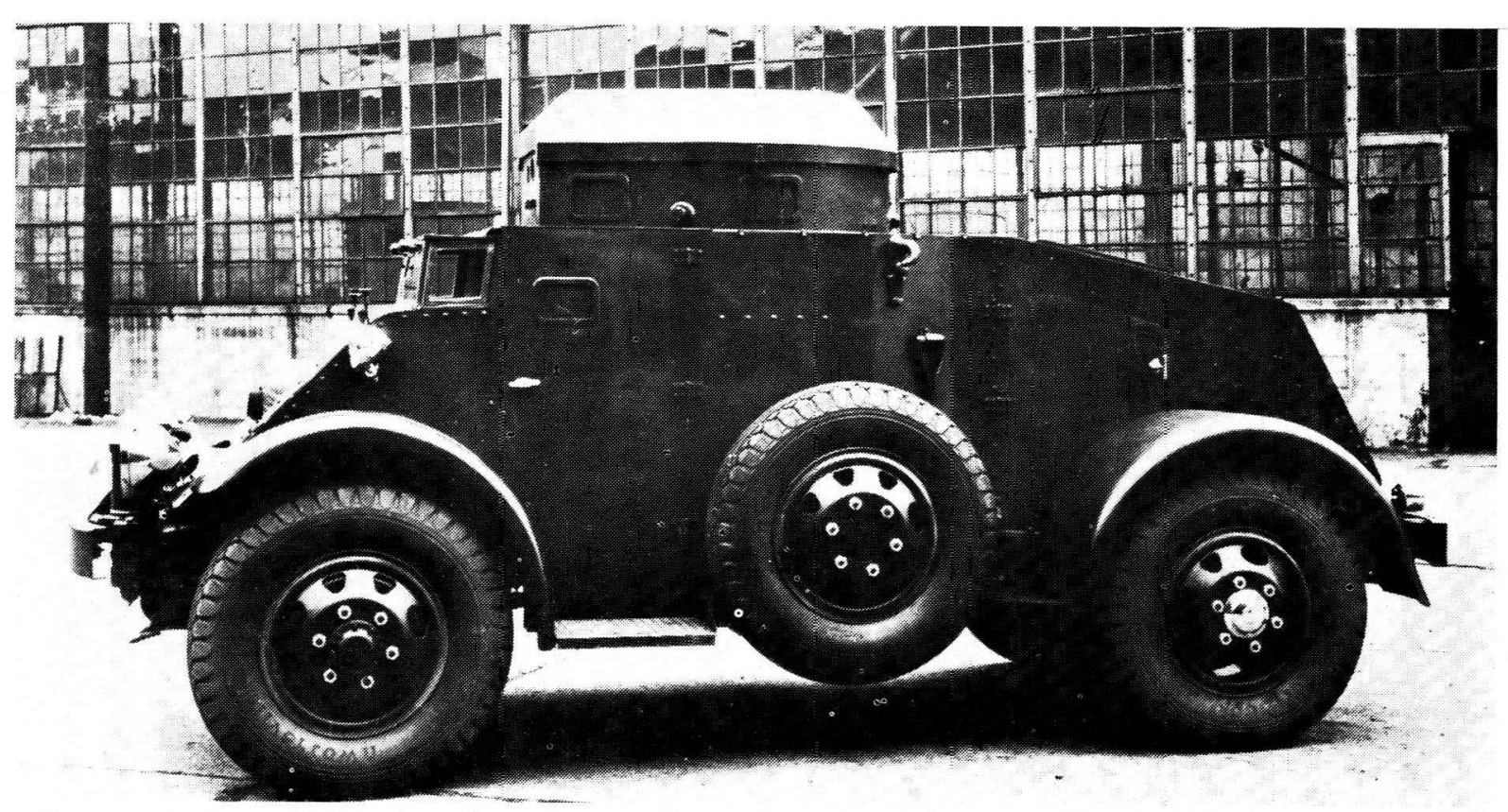

Marmon-Herrington T 11 armoured car, developed for, and experimentally accepted by, the United States Army, 1939. 

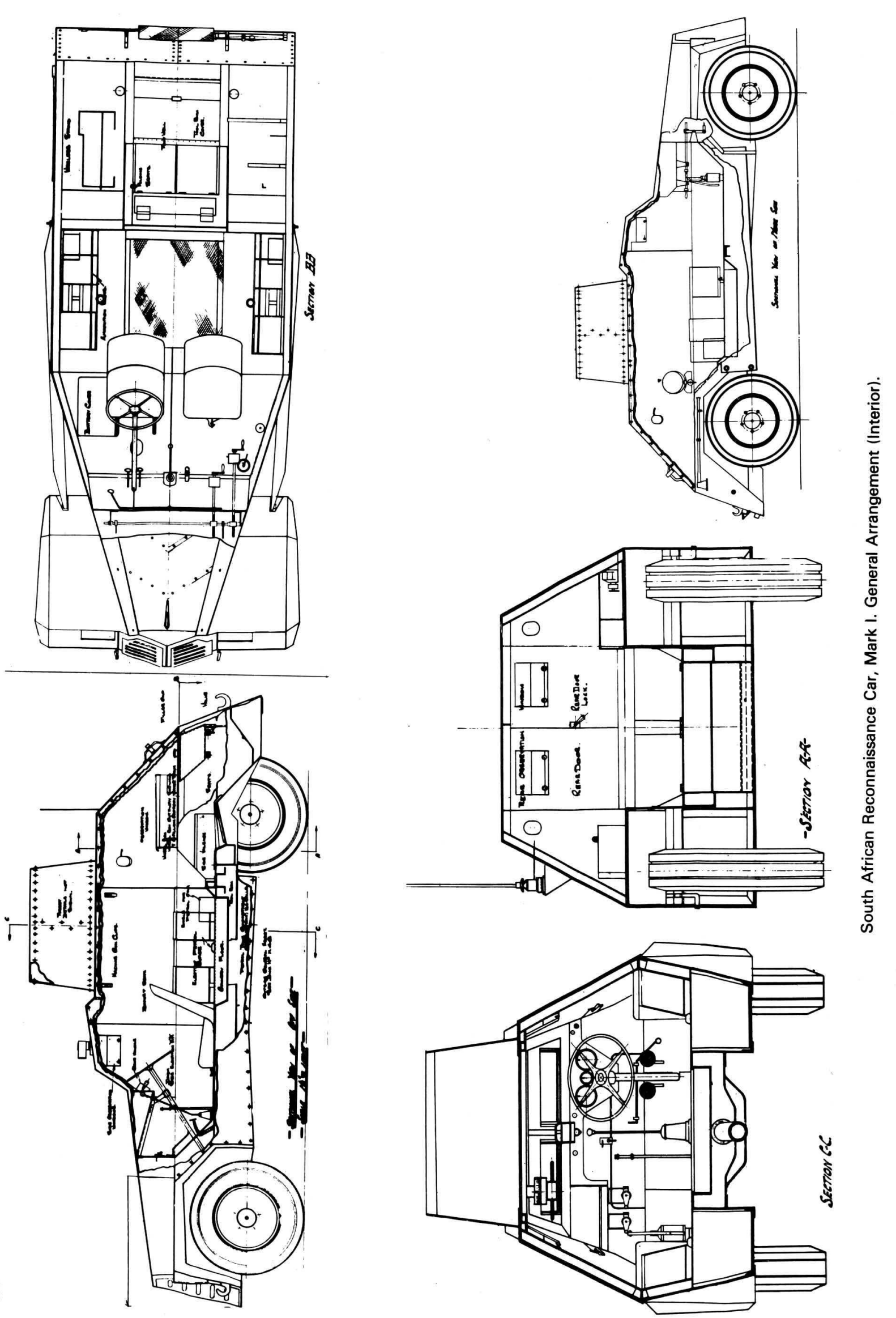

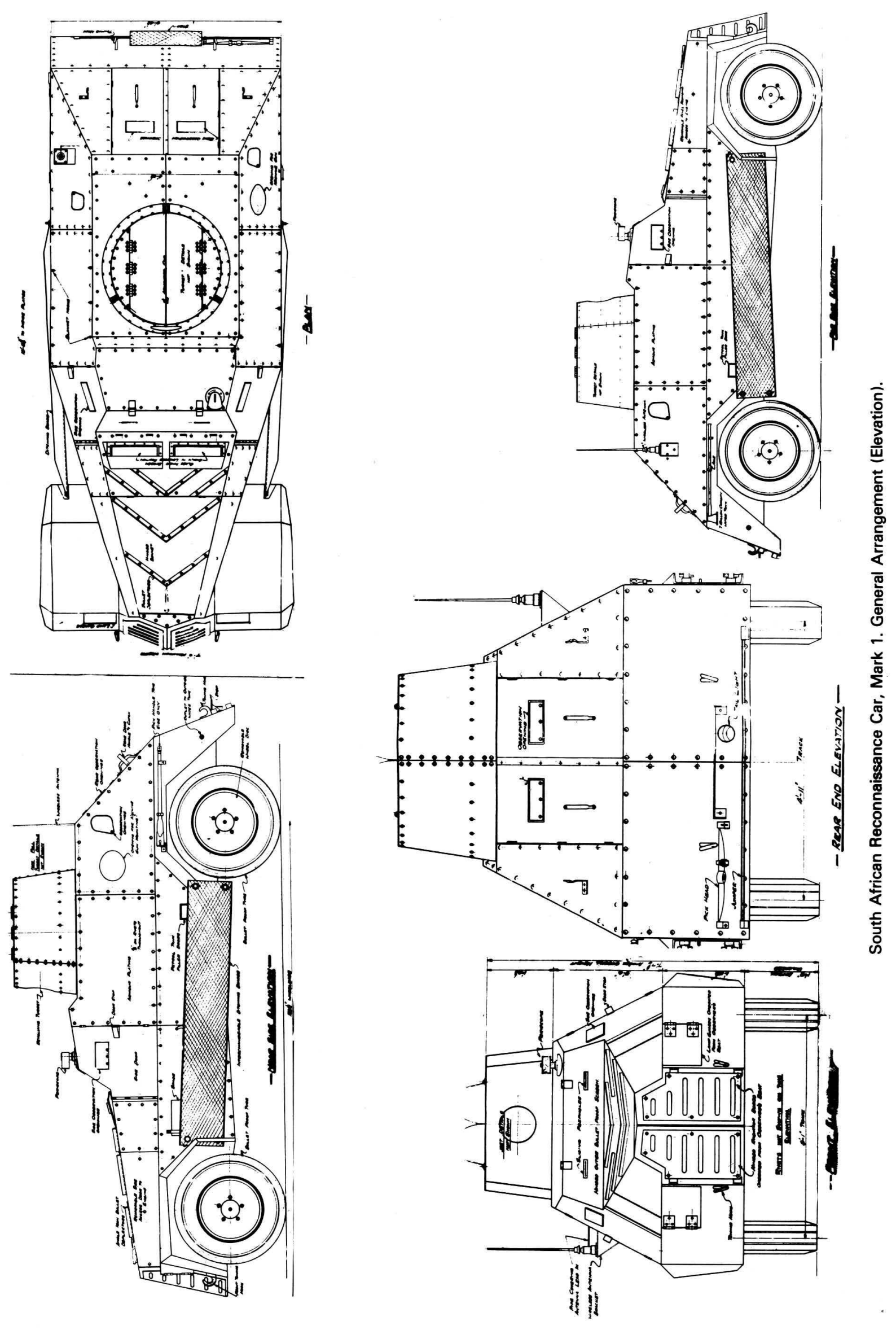


\section{Marks I and II}

The first models of South Africa's armoured car production were mounted on a standard Ford V8 3-ton lorry chassis, with a wheelbase of 134 inches and with 2-wheel drive. Early experiments showed that this design would be improved if the chassis could be modified to provide 4-wheel drive and it was discovered that the Marmon-Herrington Company could provide conversion kits to the Ford Company in Canada which would enable such a modification. Initially the two types of armoured car thus produced were simply known as Ford or Marmon Herrington, according to whether they were of 2- or 4-wheel drive. Later however the difference was classified as Mark I or Mark II. The only external differences between these two variants were the positioning of the unditching channels and the design of the front mudguards. The hull-construction in the early vehicles of both Marks was either riveted or welded on to a mild steel frame, but welded hulls were soon found to be preferable and this process was used on all subsequent models. Some modifications were also made in the course of production to the placing of the side doors. In both Marks hull, bonnet and doors were manufactured from 6-mm armour plate reinforced to $12 \mathrm{~mm}$ on the turret and the driver's visor plate.
Production of the Mark I continued until November 1940 despite the superiority of the Mark II design, because of the late delivery of Marmon-Herrington parts, and the total number produced reached 135.

The designation Mark II covered two slightly different types of vehicle, known as the MFF type, designed primarily for the Union Defence Forces' Mobile Field Force, and the ME type for the Middle East campaign. The main differences were in the armanent carried. The MFF type had an armament similar tu the Mark I, consisting of two .303 Vickers machine-guns, one in the turret and one on the left hand side of the hull, both with ball-mountings. In the ME type a rectangular opening was cut in the front of the conical turret and a nose piece welded or rivetted on. This nose piece accommodated mountings for a Bren machine-gun and a Boys anti-tank rifle, replacing the ball mounting. Also attached to the turret nose piece was a mounting suitable for a Bren gun in an antiaircraft role. The ball-mounting in the hull was replaced and a Bren-mounting substituted, while a further opening for a Bren was provided on the right hand side.

A total of 549 Mark II MFF type and 338 Mark II ME type were produced, making a total of 887 .

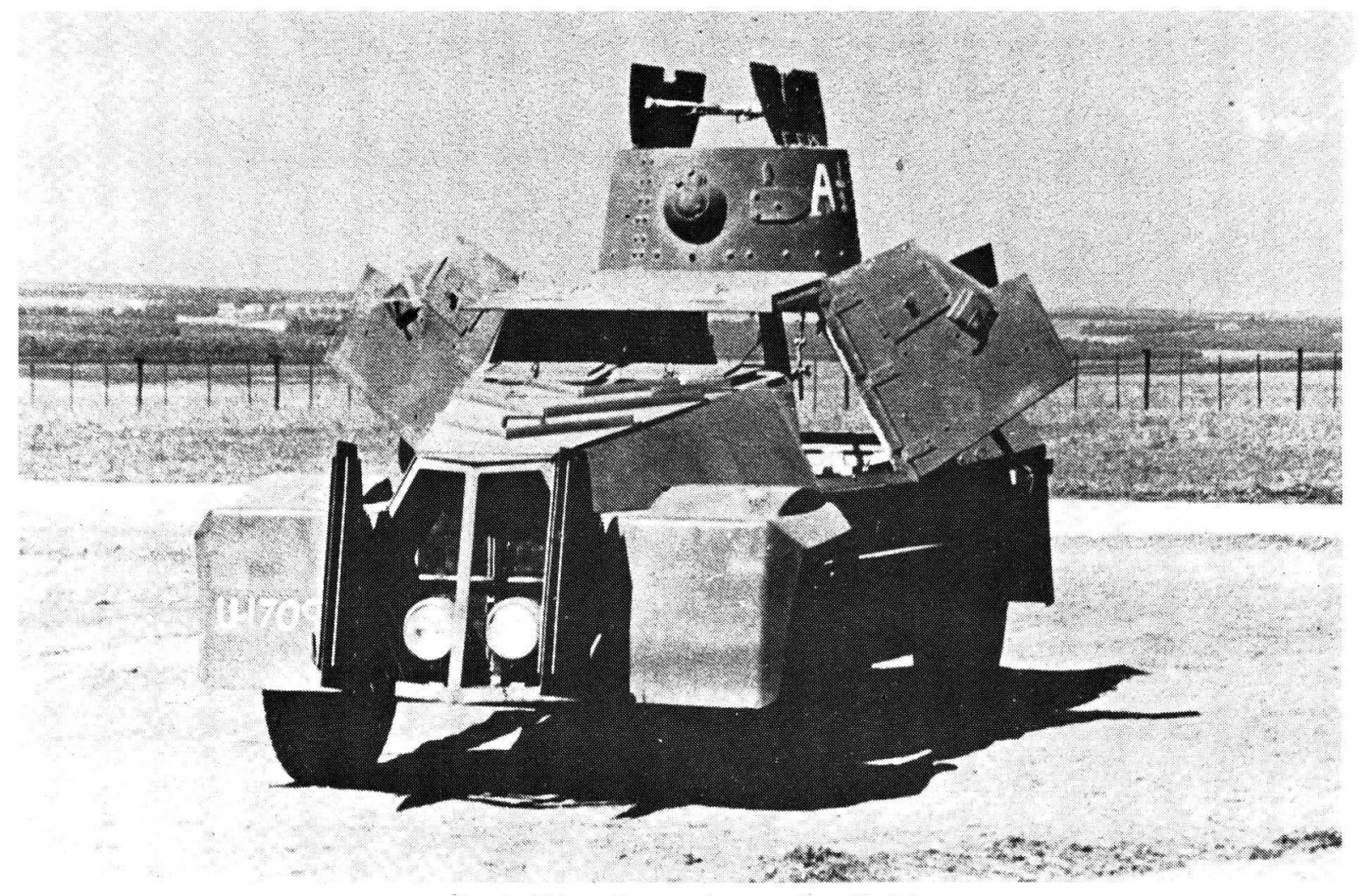

South African Reconnaissance Car, Mark I. 


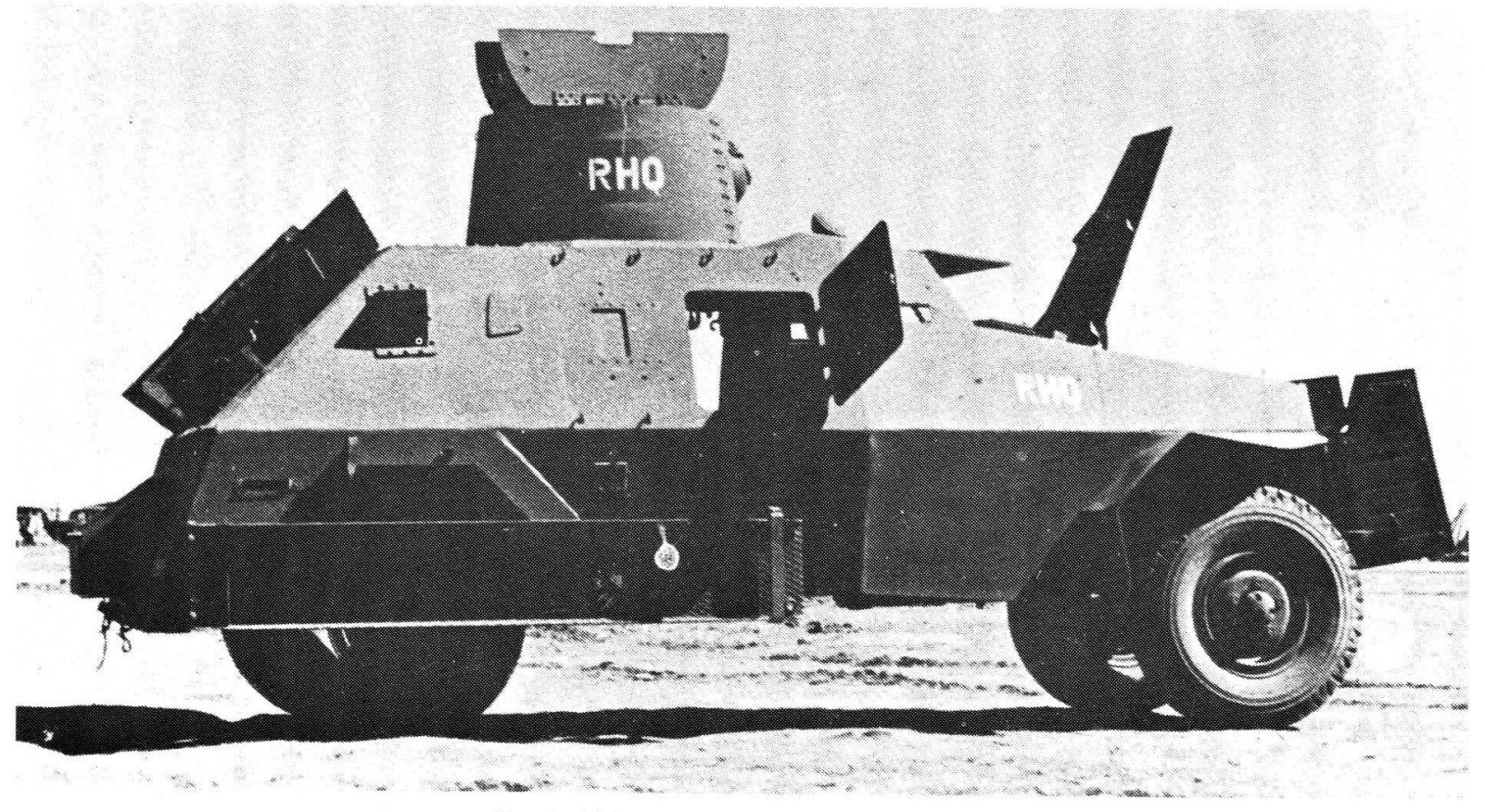

South African Reconnaissance Car, Mark II.

Once in the battle zone many modifications, authorised and unauthorised, were made to these vehicles. The adaptation of armoured cars to take heavier weapons seems already to have begun with the Mark II and in May 1941 an authorised conversion of 15 Mark II ME type was made, these vehicles being fitted with captured Italian Breda guns. Other conversions were also made as the Mark II became obsolete, and by November 1942 73 of these vehicles had been converted into LADs, (Light Aid Detachments).

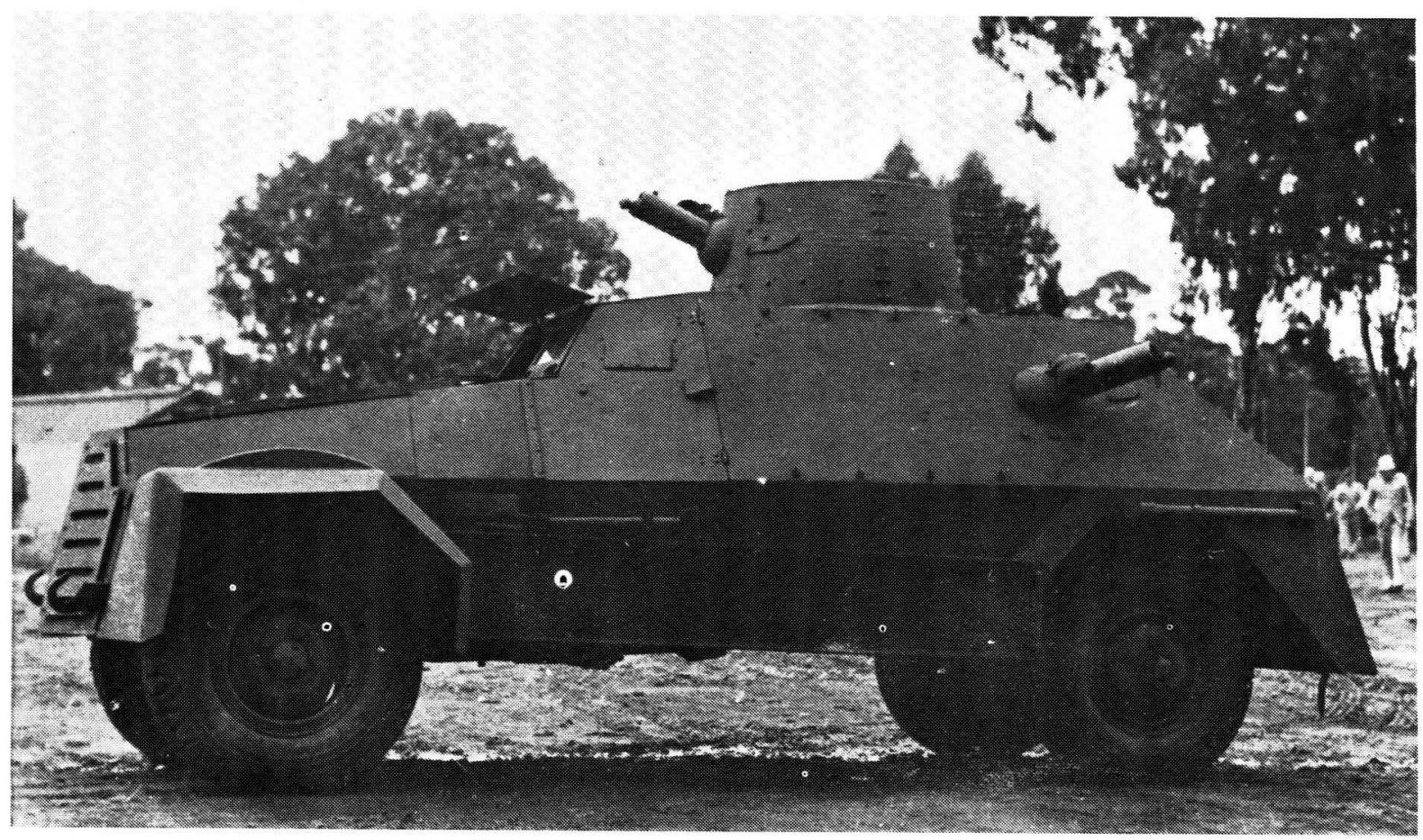

South African Reconnaissance Car, Mark I. 


\section{Mark III}

Preliminary work had already begun in September 1940 to design an armoured car with heavier protective armour than the Mark II. As the weight of the Mark II was $14000 \mathrm{lbs}$, which already placed a considerable strain on the chassis, it was obviously no answer to simply bolt on thicker plate. Instead it became necessary to think in terms of reducing the size of the car's body in order to use heavier armour, and this in turn meant reducing the number of crew to three. Once this principle had been accepted it became possible to reduce the size of the car's wheelbase, which was also advantageous from the point of view of manoeuvrability. The Mark II was therefore designed for the standard Ford 3-ton 134inch wheelbase shortened to $1171 / 2$-inches and provided, like the Mark II, with 4-wheel drive and a Marmon-Herrington front axle assembly, powered by a Ford V8 $85 \mathrm{hp}$ engine.

With this hypothetical design in mind, experts from the Union visited the East African theatre to discuss the new car with the local military authorities and with representatives from Cairo. The general lines of the new design met with approval, but certain new suggestions were made. The armour experts in the field felt that the thick- ness of the car's armour was probably less important than its mobility; that under some circumstances it would be necessary to accommodate a fourth crew member; and that greater attention should be paid to the internal finish of the vehicle to provide for the comfort of the crew.

These discussions led to further modifications of the initial design and a prototype was successfully tested at the end of December 1940. The general specifications were not so different from those of the Mark II except for the shorter wheelbase, described above. The front axle had been strengthened, the springs improved and a heavier pattern of steering box introduced. The general configuration of the body remained very similar to that. of the Mark II, although the angles of the armour had been improved and the round turret was replaced by an octagonal one. The general thickness of the armour plate in the hull remained 6-mm, but full 12-mm protection was provided on all forward-facing parts. Despite this additional protection the laden weight of the vehicle amounted to only $12000 \mathrm{lbs}$.

Other improvements included the elemination of the opening radiator doors of the Mark II design; these were replaced by a fixed nose, made possible by the addition of an auxiliary radiator system.

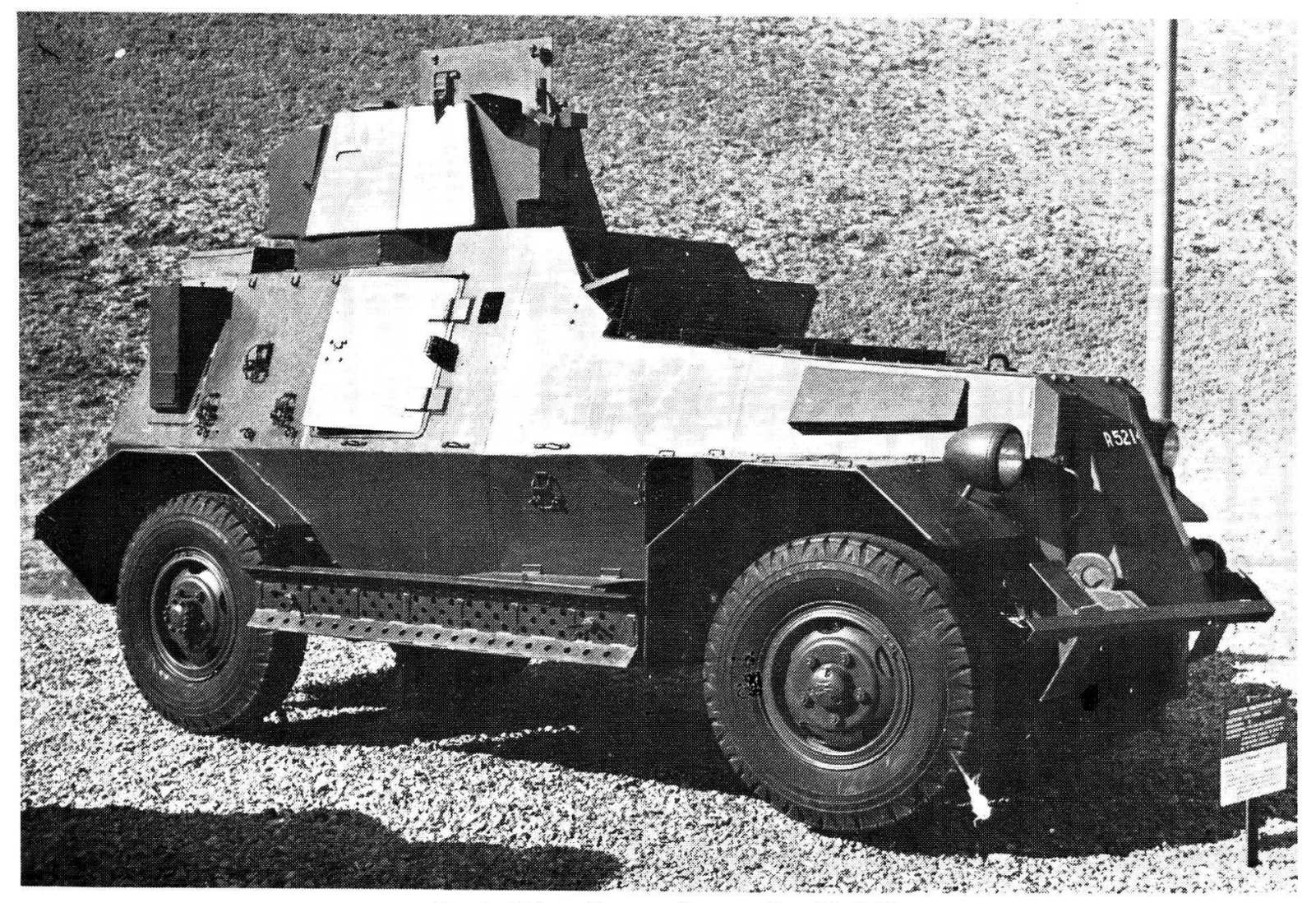

South African Reconnaissance Car, Mark III. 
The Mark III also dispensed with the twin doors at the rear of the hull. The turret too was redesigned to accommodate a Vickers machine-gun and a Boys anti-tank rifle in the MFF type or a Bren and Boys anti-tank rifle in the ME type. Although the two types ME and MFF were retained as in the Mark II series, the Mark III was so designed as to ensure the easy conversion of the one to the other. A Bren gun mounting was provided for anti-aircraft use, along with Bren slots in the car's hull, but the second Vickers, carried in the hull of the Mark II MFF type was omitted in the Mark III.

Quantity production of the Mark III began in May 1941 and ended in August 1942, and during this time some further improvements were made to the design. The original vehicles, for instance, had horizontal armoured radiator grilles and square headlamp covers, but in later variants solid front armour replaced the grilles and the headlamp covers were omitted altogether. A single rear door was also incorporated in later models as an additional escape hatch, and this necessitated the moving of the spare wheel to the right hand side of the hull. In addition to these approved design modifications, the units operating these vehicles made many 'unofficial' changes, particularly to the armament. In the Western Desert especially the need was felt for a more potent antiarmour weapon than the Boys rifle and some Mark IIIs were equipped in the field with anti-tank guns of both Allied and Axis manufacture.

By the time production of the Mark III ended in August 19422260 had been built, 1780 MFF type, $798 \mathrm{ME}$ type and $52 \mathrm{MFF}$ type converted into Light Aid Detachments. Unlike the Mark II this production was not intended for use just in the Middle East or in East Africa: of the MFF type 255 were sent to India; 175 to Malaya; 49 to the Netherlands East Indies where some fell into Japanese hands in 1942; 10 to the Free French forces at Brazzaville; 60 to British West Africa and 6 to Mozambique; of the ME type 48 were despatched to the Free French forces in the Middle East and 24 to Southern Rhodesia.

\section{Mark IV}

Attempts to produce an armoured car with more powerful armament were already well under way by September 1941 when a new 4-wheel drive car with a 2-pdr armament underwent trials; this was to become the South African Reconnaissance Car Mark IV. Ford and Marmon Herrington components were again used, but the conventional chassis was abandoned and suspension, engine and transmission were bolted directly into the welded armour of the hull. The Ford engine was situated in the rear of the vehicle and drove through its standard gear-box and a 2:1 auxiliary box into a locally-made transfer box also in the rear; thence a propeller shaft was led forward to the MarmonHerrington transfer box which drove both axles.

Considerations of weight prevented this vehicle being given any greater protection than the Mark III although the latter had proved to be somewhat vulnerable to an attack. The Mark IV therefore retained 6-mm armour at the sides and $12-\mathrm{mm}$ in front, but the angles were improved to afford better protection.

The ascommodation of a 2-pdr gun in the Mark IV's turret did create some problems, for the structure was too light to absorb the short recoil of a 2-pdr tank mounting. Eventually an opentopped turret was designed capable of holding two crew and a 2-pdr anti-tank gun with a field recoil mechanism, mounted on trunnions and firing through a loophole in the turret's front plate. A bracket on the left hand side of the gun allowed the mounting of a No 24 telescope for sighting. There was no co-axial machine-gun in the initial design but later variants had a .303 Vickers or .30 Browning in a coupled mounting. An antiaircraft mounting was provided on top of the turret for a 50 Browning, which could also be used against ground targets. Despite the shortcomings of this design it was hoped that the Mark IV would help tide the Allied forces in North Africa over an awkward period, until better designed and more heavily armed vehicles were produced in the United States or Britain.

Production of the Mark IV began in July 1942, and in the first models, later designated Mark IV $X$ the reat engine was mounted facing forward with the gearbox behind it and with a radiator in the rear of the car taking in air through the rear of the hull. This configuration was soon discovered to be unreliable and the transmission was redesigned after only 96 Mark IV Xs had been completed. In the subsequent Mark IVs the engine faced the rear with the gearbox in front, and air entered from the fighting compartment through a radiator mounted on the dividing bulkhead.

Between July 1942 and April 1944, when production ceased, some 936 Mark IVs had been manufactured to this basic design; of these, however, only 310 were equipped with 2-pdr armament, the remaining 626 being armed merely with machine-guns, to be used in an internal security role. 
Manufacture of the Mark IV was continually held up by the need to wait for the delivery of parts from America and Britain, and when the British War Office placed an order for an additional 1180 Mark IVs for use in the Middle East it was decided that steps would have to be taken to circumvent the delays created by the irregular delivery of Marmon-Herrington Ford parts. It was decided that the Canadian Ford F60L 3-ton lorry chassis, already on order for the War Office could be used. This variant was named Mark IVF and was armed with the 2-pdr and a co-axial .30 Browning plus a 30 Browning on an anti-aircraft mounting. Delivery of the Mark IVFs began in May 1943. The basic specifications of the Mark IV were as follows:

\section{Mark IV Armoured Car:}

Crew: Three men.

Armament: Q.F. 2-pdr coupled with a .303 Vickers machine-gun. Anti-Aircraft 50 Browning machinegun. Sten M.G. Verey-light pistol.

Armour: 12-mm front of hull. Remainder 6-mm with exception of 4-mm under driver's compartment.

Turret: Base ring 48" diameter. Hand operated spur - gear traverse. Time of traverse $90^{\circ} 5 \mathrm{se}$ conds, $180^{\circ} 10$ seconds, $270^{\circ} 16$ seconds, $360^{\circ} 22$ seconds.

Ammunition: 2-pdr. 37 rounds. 303 V.M.G. 750 rounds. 5 Browning M.G. 1000 rounds.

Engine: Ford V8 85 BHP.

Maximum Torque: $155 \mathrm{lb}-\mathrm{ft}$

Gear Box: 45 speed and reverse. Top 1/1, 1.69/1, $3.09 / 1,6.4 / 1$. Final drive bevel $6.67 / 1$. Overall reduction not in auxiliary low: $-42.69 / 1$ in 1 st gear, 20.6/1 in 2nd gear, 11.2/1 in 3rd gear, $6.67 / 1$ in Top, 52.2/1 in Reverse. Auxiliary low 2/1.

Axles: Front axle Marmon-Herrington. Rear axle Ford Standard with Marmon-Herrington attachment. Four wheels driven.

Tyres: $9.75 \times 18$ imparted into axles replaced by $10.50 \times 16$ run flat tyres in Middle East.

Weight: Fully stowed 13900 lbs.

Maximum Speed: $52 \mathrm{mph}$.

Fuel Capacity: 40 gallons range 360 miles.

Wheel Base: 9'10'.

Brakes: Ford Hydraulic

Overall Dimensions: Length 17'10'. Width $7^{\prime}$. Height 7'6". Track - Front 59", Rear 60". Wireless Set: No. 19.

\section{Mark IV F Armoured Car for Mid East Forces} Crew: Three men.

Armament: Q.F. 2-pdr. co-axial with .30 Browning. Anti-aircraft, 30 Browning M.G. Thompson Sub machine Gun. Verey light pistol. Two 4-inch Smoke dischargers

Armour: 12-mm Front of Hull, front and sides of turret and a round driver's compartment. Remainder 6-mm with exception of 4-mm under driver's compartment and under two observation seats on turret.

Turret: Base ring 48" diameter. Hand operated spur gear traverse. Time of traverse: $90^{\circ}-5$ seconds, $180^{\circ}-10$ seconds, $270^{\circ}-16$ seconds, $360^{\circ} \rightarrow 22$ seconds

Ammunition: 2-pdr 53 rounds A.P. .30 Browning 2250 rounds. Thompson 200 rounds. Verey light 12 rounds, Smoke generator 6 rounds.

Engine: Ford V8 Mercury 95 BHP.

Gear Box: 4 speed and reverse. Top 1/1, 1.69/1, 3.09/1, 6.4/1. Final drive bevel 7.16/1, Overall reduction not in auxiliary low; $45 / 1$ in 1 st gear, $22 / 1$ in 2nd gear, $12 / 1$ in 3rd gear, $7.16 / 1$ in Top gear, 56/1 in Reverse. Auxiliary low ratio $1 / 87 / 1$. Drive on all four wheels.

Suspension: F60L Modified rear springs on front and rear axle.

Tyres: $10.50 \times 20$ run flat.

Gross Weight: Fully stowed 14880 lbs. Not stowed $12740 \mathrm{lbs}$.

Maximum Speed: $52 \mathrm{mph}$

Miles per Gallon: Road 51/2; across country $3 \frac{1}{2}$.

Fuel Capacity: 40 gallons.

Wheel Base: 9'10'

Brakes: Ford Hydraulic.

Overall Dimensions: Length 18'11/2'". Width $7^{\prime}$. Height 7'6". Track 69"

Wireless Set: Number 19, intercommunication through No. 19 set.

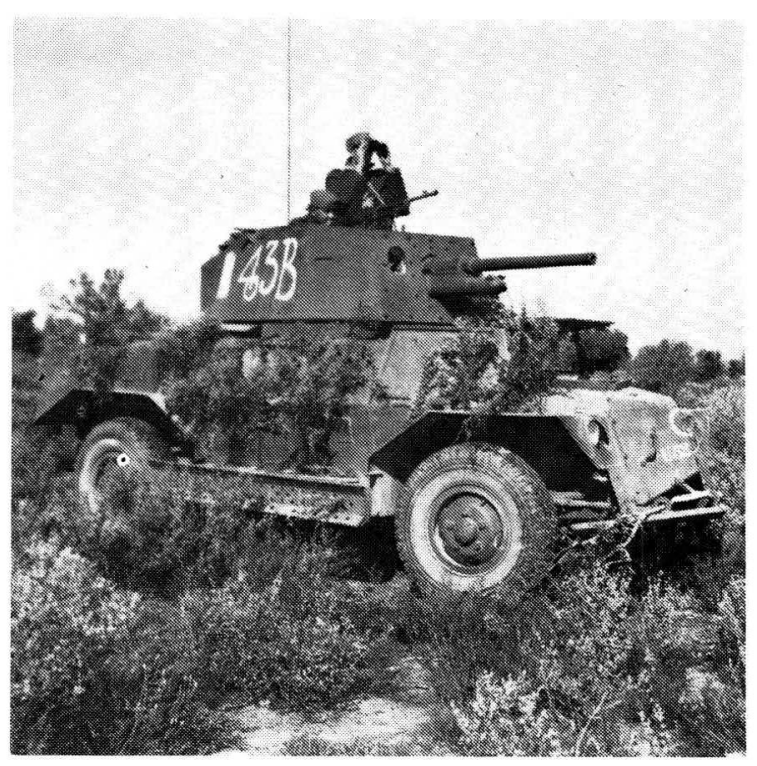

South African Reconnaissance Car, Mark IVF. 


\section{Mark V}

Apart from the main production models of the South African Reconnaissance Cars, several experimental projects were undertaken during the course of the war which, although expected to result in extensive production, scarcely went beyond the prototype stages. In April 1941 the military authorities in the Middle East were already suggesting that the Union undertake the production of heavier armoured cars. As a result the South African Director General of War Supplies undertook the development of an eight-wheeled armoured fighting vehicle later called the Mark $V$. This was to be an eight-wheeled heavy armoured car, powered by two 150/160 BHP Albion petrol engines. The frontal armour was to be $40-\mathrm{mm}$ with $20-\mathrm{mm}$ on the sides, and the chassis was designed primarily to mount a 6-pdr anti-tank gun and one heavy anti-aircraft machine gun. It was also proposed to experiment with this vehicle as a mounting for a self-propelled 25-pdr.

The chassis was first tested in February 1942 and a mock-up of the finished product was despatched to the Middle East for further tests in August. The heavy chassis, 16 tons in weight, and fourwheeled drive proved unsuited to desert conditions, however, and the project was gradually abandoned as better designs came to the fore.

\section{Mark VI}

In August 1941 orders had already been placed for two Warford chassis to enable work to commence on a lighter 8-wheeled armoured car. The Warford bogies would be used to house Marmon Herrington axles, and it was anticipated that even this lighter 8-wheeler would be capable of carrying twice the load of the heaviest models then in production, enabling a $75 \%$ improvement in armour.

By November 1941 the construction of the body, designed to take a 2-pdr gun, was nearing completion. The Director General of Technical Services had stipulated that the vehicle should also be capable of housing the new 6-pdr gun, but the designers had doubts about the feasibility of this and indicated that a 6 -pdr would require a turret with a length of 8 feet.

In January 1942 a new development occurred in the progress of the 8-wheeler's design when the Director of Technical Services had talks with the Ford Company, who were working on an 8-sheeler armoured car code named 'Betsey'. This was possibly the T18 8x8 project, known in British circles as 'Boarhound', although the details provided to South Africa were certainly not identical to those of the T18. In any event it was felt that the performance of this vehicle was superior to that of either of the projected South African vehicles and that the chassis might provide a suitable base for a South African hull.

Nonetheless the South African project continued and the Mark VI designed emerged, powered by two Ford V8 95 hp engines, with Ford clutches and gearboxes coupled at the output end of the gearboxes with the transfer box. The output of the transfer box drove the front three axles. The front and back axles were Marmon-Herrington, the other two being Warford, all mounted in two Warford 5-ton bogies, and steering was provided to front and rear axles. The prototype weighed about $25000 \mathrm{lbs}$ and was capable of a top speed of $40 \mathrm{mph}$.

In February 1942 the serious turn of events in the Far Eastern theatre persuaded the South African defence authorities of the need to produce 500 of these heavier cars to defend domestic installations against the possibility of a Japanese invasion

It was also important to keep armoured car production running until Britain decided to place further orders, and it was felt that South Africa could produce 8-wheelers in advance of the United States to meet an order for 250 from the Middle East.

By April a turret had been designed to house a 2-pdr gun with a 30 Browning co-axially mounted. For anti-aircraft defence a twin .30 Browning mounting was provided, arranged to traverse around the open top of the turret. The turret ring was also large enough to take a 6-pdr with tank recoil, and further progress was being made to allow this heavy armament. In November 1942 a pilot model with 2-pdr was despatched to the Middle East for trials

Already in December 1942, however, there were delays in the delivery of the first sets of components from North America and this was expected to hold up production in South Africa until August 1943. Nevertheless, a second prototype, mounting a 6-pdr gun, was tested in January 1943. By now, however, the North African campaign had undergone a dramatic change, the urgency for the production of an 8-wheeler diminished and by September 1943 the British authorities cancelled their order for 250 cars. Still the South African authorities persisted with the development, although cutting their own requirement to 100 cars in January 1944 . But by October 1944 the development was restricted to the 
drawing board and shortly after the end of the war the project was abandoned altogether.

The specifications of the Mark VI were as follows:

\section{Mark VI Armoured Car:}

Crew: Four men, three in turret.

Armament: Q.F. 2-pdr co-axial with .30 Browning machine guns.

Armour: $40-\mathrm{mm}$ basis front. $20-\mathrm{mm}$ basis, sides of fighting compartment. $14-\mathrm{mm}$ basis, sides of engine compartment. $20-\mathrm{mm}$ basis rear. $10-\mathrm{mm}$ roof.

Turret: 57" diameter ring. No roof. 42" diameter to $57^{\prime \prime}$ diameter rotating platform. Open top with Anti-Aircraft ring mounting. 2-4" Smoke Dischargers. Electric power traverse. Number 9 Wireless Set.

Ammunition: 2-pdr. 80 rounds. 30 Browning 4250 rounds. Smoke 30 rounds. Thompson Sub Machine Gun 300 rounds.

Engine: Two Ford Mercury 95 horse power. Two Ford 4 speed and reverse gear boxes (ratios as for Mark IVF).
Transfer Box: (Combining two drives into one). Radio 1/1.5. Final drive bevel 6.66/1. Total reduction 64/1.

Suspension: Two Semi-Eliptic Warford Bogies. Axles: Front and rear steered; all driven. Front: Marmon-Herrington. Nos 2 and 3 Warford. Rear: Marmon-Herrington.

Tyres: $10.50 \times 20$ run flat.

Gross Weight: 24640 Ibs approximately. Maximum speed 40 mph at 3800 RPM engine speed. 45 mph at 4200 RPM engine speed.

Fuel Capacity: 60 gallons.

Range: 250 miles.

Turning Circle: 45' diameter.

Wheel Basis: 11'3".

Bogie Centres: 45".

Wheel Track Centre: 5'1".

Brakes: Hydraulic all wheels.

\section{Mark VII}

In February 1942 a South African ring mounting for a Vickers .303 machine-gun was given its first

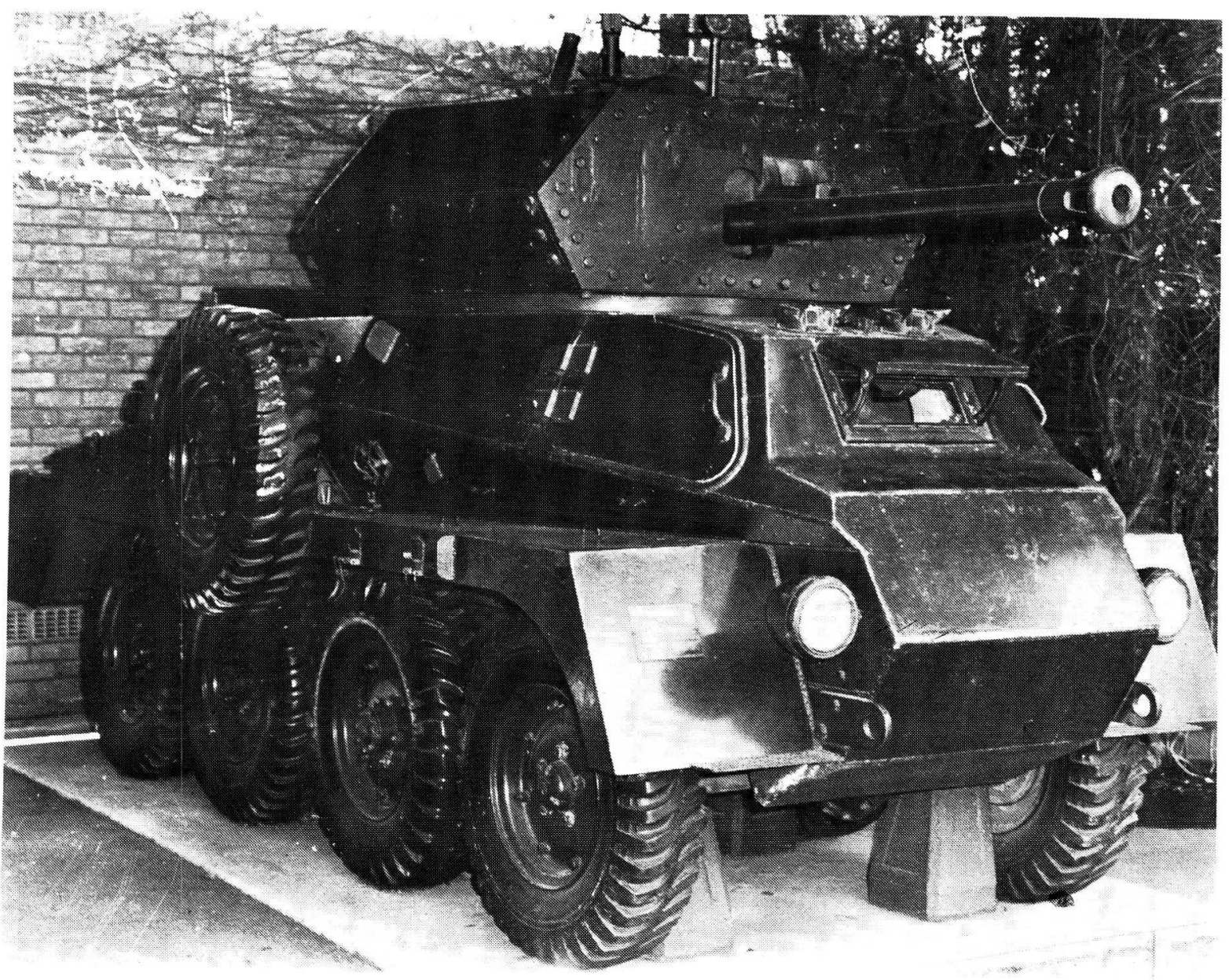

South African Reconnaissance Car Mark VI, now at the SA National War Museum, Saxonwold. 
firing tests and it was suggested that this mounting, perhaps adapted to take twin 0.5 Vickers guns might be built into a specially designed light armoured car. After further successful tests with the mounting on a Mark III car, approval was given for a mock design to be called Mark VII, and in June 1942 authority was given for the construction of a prototype. The chassis was identical to that of the Mark III and the hull was of angular construction, welded throughout, with the minimum number of plates, large doors, no turret and a low centre of gravity. Tests carried out in July 1942 indicated that as a small arms car the Mark VII was better than either the Mark III or IV, but despite this promising start it was decided by November 1942 that South Africa could really only hope to produce one basic type of car at any one time and that, as a small arms vehicle, the Mark VII enjoyed a far lower priority than cars armed with anti-tank weapons. The Mark VII project was therefore abandoned.

The specifications of the Mark VII are given below.

\section{Mark VII Armoured Car:}

Crew: Four.

Armament: Dual mounting ground and AA for single or twin $.5^{\prime \prime}$ or $.303^{\prime \prime}$ MG's fitted on ring mounting.

Armour: 6-mm all over.

Turret: Replaced by ring mounting. 36" inside diameter, shield on ring.

Engine: Ford V8 85 BHP.

Gear Box: Ford 4 speed \& reverse. Top: $1 / 1$. 3rd: 1!.69/1. 2nd: 3.09/1. 1st: 6.4/1. Reverse: $7.83 / 1$.

Auxiliary Gear Box: 2/1.

Final Drive: 6.67/1.

Steering Ratio: 18.4. :1.

Suspension: Ford Standard.

Axles: Front: Marmon-Herrington steered and driven. Rear: Ford Standard.

Tyres: $9.75 \times 18$.

Gross Weight: Front: Marmon-Herrington steered and driven. Rear: Ford Standard.

Tyres: $9.75 \times 18$.

Gross Weight: 5 tons (short) 8000 lbs unladen (weighed). $2000 \mathrm{lbs}$ equipment (estimated).

Tractive Effort: $9880 \mathrm{lbs}$.

Power WT Ratio: 17.0.

Fuel Capacity: 35 gallons.

Turning Circle: R. 52'. L. 47'.
Wheel Base: 1171/2"

Track Centres: Front 61". Rear 59".

Brakes: Foot - hydraulic. Hand - mechanical. Overall Height: $6^{\prime} 6^{\prime \prime}$ top of car, $7^{\prime} 10^{\prime \prime}$ top of gun. Dimensions: Length - 16' $8^{\prime \prime}$. Width - 7'7' Height $-6^{\prime} 6^{\prime \prime}$ top of gun $7^{\prime} 10^{\prime \prime}$.

Reserve Water: Radiator 8 gals. Drinking 8 gals.

Range Miles: 200 miles (7 mpg).

Cooling: Standard Ford radiator in front.

Max Speed (approx.): $70 \mathrm{mph}$ - on roads.

Cruising Speed (approx.) $45 \mathrm{mph}$ on roads.

\section{Mark VIII}

In September 1942 yet another armoured car design got under way when the Director General Technical Services was requested to provide a vehicle to fulfil the following requirements:

(i) A high degree of manoeuverability with a range of at least 200 miles cross country. Speed - cross country $40 \mathrm{mph}$. A road speed higher than $55 \mathrm{mph}$ is immaterial.

(ii) Wireless. Good accommodation for a No 19 set and the wireless operator.

(iii) Armament. (a) S.A. Cars twin mounting for .303 and .5 M.G.'s for use singly or together against air and ground targets.

N.B. Consideration should be given to an alternative mounting for a $20 \mathrm{~mm} \mathrm{A.A.} \mathrm{gun}$

(b) 2 pdr cars. $2 \mathrm{pdr}$ A.T. gun and a .5 M.G. against ground and air targets.

(iv) Ammunition S.A. cars -1000 rounds .5 M.G. 1500 rounds .303 2-pdr Cars - 35 rounds 2-pdr. 1500 rounds 5 .

(v) S.A. Car crew four -2 pdr Car crew three. (iv) Water, kit etc. as in Mk VII (experimental). (vii) Power-weight ratio not less than 17. (viii) After providing for (i) to (vii) above immunity should primarily be given against attack from $10^{\circ}$ above the horizontal.

By September 1943 the mock-up had been constructed and a satisfactory hull with a standard Ford F60L axle and transmission assemblies developed. Firing trials to prove the turret design were successful and all indications were that the Mark VIII would prove a marked improvement on previous $4 \times 4$ cars. This project also got no further than iis prototype stage however, probably for the same reasons as the Mark VI and VII. 